\title{
Wood Chips and Compost Improve Soil Quality and Increase Growth of Acer rubrum and Betula nigra in Compacted Urban Soil
}

\author{
Bryant C. Scharenbroch and Gary W. Watson
}

\begin{abstract}
Tree growth is negatively impacted by the removal of topsoil and compaction of subsoil associated with site development in urban landscapes. A research plot with 60 Acer rubrum and 60 Betula nigra was created, mimicking the typical urban landscape disturbance. Wood-chip mulch (WC), compost (COMP), inorganic fertilizer (FERT), aerated compost tea (ACT), a commercial biological product (CBP), and a water control (NULL) were assessed for their impacts on soil quality and tree growth after five years. The WC treatment significantly decreased bulk density and increased soil moisture, organic matter, and microbial respiration. The COMP treatment increased soil moisture, organic matter, microbial respiration, $\mathrm{pH}, \mathrm{N}, \mathrm{P}$, and K. Soil P increased with the FERT treatment. Tree growth was significantly increased with WC, COMP, and FERT treatments. No significant changes in soil properties or tree growth were observed with ACT or CBP compared to NULL; and, compared to background soil levels or other treatments (e.g., COMP and WC) ACT and CBP supply relatively minimal amounts of microbes and nutrients. This research shows strong evidence that COMP topdressings and WC mulches are effective and also cost-efficient methods for improving soil quality and stimulating tree growth in compacted urban landscape soils.

Key Words. Acer rubrum; Aerated Compost Tea; Betula nigra; Compost; Inorganic Fertilizer; Organic Materials; Organic Matter; Soil; Wood-Chip Mulch.
\end{abstract}

Topsoil scraping and subsoil compaction are often necessary to prepare sites for infrastructure. The removed topsoil (O and A horizons) is a substantial loss of soil organic matter ( $\mathrm{SOM}$ ) and nutrients. Compaction of the subsoil (B horizons) destroys the soil structure that is important for soil porosity, aeration, proper drainage, and root extension (Unger and Kasper 1994). Topsoil removal and subsoil compaction have severe negative impacts on soil quality which directly hinder the establishment and growth of urban trees.

Inorganic fertilizers are often applied to supplement nutrient cycling in urban landscapes that have had the topsoil removed. A substantial body of literature has demonstrated tree growth improvements with inorganic fertilizers (e.g., van de Werken 1981; Watson 1994; Struve 2002; Percival and Barnes 2005). However, many studies also show negative effects associated with inorganic fertilizers, including: ground and surface water contamination (Mitsch et al. 2001; Driscoll et al. 2003;
Soldat and Petrovic 2008), gaseous losses of soil carbon (C) (Khan et al. 2007; Mulvaney et al. 2009) and nitrogen (N) (Vitousek et al. 1997; Jenssen and Kongshaug 2003) and soil salt accumulation (Follett et al. 1981; Finck 1982). Furthermore, inorganic fertilizers have been found to impact plant resource allocation and may lead to decreases in defensive compounds and increased herbivory (Herms and Mattson 1992). The recommended annual rates for landscape tree fertilization are 1 to $3 \mathrm{~kg} \mathrm{~N} 100 \mathrm{~m}^{-2} \mathrm{yr}^{-1}$ (ANSI 2004; Smiley et al. 2013).

Organic materials used as mulches and amendments are also applied to urban landscapes to improve soil quality (Finck 1982). Chipped and tub-ground hardwood mulch and compost are two of the most highly utilized organic materials in urban landscapes. Comparatively, wood chips are coarser, have a wider $\mathrm{C} / \mathrm{N}$ ratio, and decompose more slowly. Compost on the other hand, is fine textured, $\mathrm{N}$ rich, and rapidly decomposes. Both types of organic materials have been found to positively 
impact soil properties and tree growth [see reviews by Chalker-Scott (2007) and Scharenbroch (2009)]. Beneficial effects of these organic materials include improved soil moisture, reduced erosion and compaction, maintenance of optimal temperature, reduced salt and pesticide use, increased binding of heavy metals, reduction of weeds, improved soil fertility, improved plant establishment and growth, and reduction of disease (Chalker-Scott 2007). Current standards do not exist for application rates of organic materials. Wood-based mulch is often applied annually to depths of 5 to $15 \mathrm{~cm}$ around the tree, but not against the base of the tree. Saebo and Ferrini (2006) suggest no more than 1.0 to $1.2 \mathrm{~kg}$ of plant available $\mathrm{N} 100 \mathrm{~m}^{-2} \mathrm{yr}^{-1}$ to be delivered from compost.

Clients and circumstances often dictate that turfgrass remain under urban trees in lieu of mulch. Furthermore, mulch rings rarely cover the full extent of the rooting area, which has been estimated to be 38 times the tree diameter (Day et al. 2010). Liquid-based organic products and materials (e.g., compost tea, humic acids, mycorrhizal spores) are gaining popularity for applying nutrients and organisms to soils for landscape trees.

Aerated compost tea (ACT) is a mixture of compost, organisms, additives, and aerated water (NOSB 2004). According to the National Organic Program (NOP), the predominant ACT production method in the United States involves one part compost in 10-50 parts water, constant aeration for 12 to 24 hours, and immediate application (NOSB 2004). NOP standards specify that compost used to make ACT must be made from allowable feedstock materials and the entire pile must undergo an increase in temperature to at least $131^{\circ} \mathrm{F}$ for at least three days (NOSB 2002). ACT additives, such as molasses, yeast extract, and algal powders are used to encourage growth of beneficial microbes. No standards exist for application rates of ACT in agriculture or horticulture. Suggested ACT application rates for urban landscape plants range from 500 to $5,000 \mathrm{~L}$ ACT $100 \mathrm{~m}^{-2} \mathrm{yr}^{-1}$ (E. Ingham of Soil Foodweb, Inc., July 2008, pers. comm.), albeit these rates are not based on scientific evidence.

It is suggested that ACT will increase nutrient availability and retention via microbial mineralization and immobilization, build soil structure and decrease the effects of compaction, detoxify soil and water, and suppress disease by inducing com- petition among disease (anaerobic) and beneficial (aerobic) organisms (e.g., Ingham 2003a; Ingham 2003b; Ingham 2004; Lowenfels and Lewis 2007). However these claims are unsubstantiated and few peer-reviewed controlled, replicated scientific studies have been performed on the impacts of ACT on plants, soil, and the environment (Scheuerell and Mahaffee 2004; Duffy et al. 2004; Scheuerell and Mahaffee 2006; Larkin 2008; Segarra et al. 2009). Even fewer studies have examined ACT with urban trees (Scharenbroch et al. 2011; Scharenbroch 2013; Scharenbroch et al. 2013).

The objective of this research was to evaluate inorganic fertilization (FERT), wood chips (WC), compost (COMP), aerated compost tea (ACT), a commercial biological product (CBP), and a water control (NULL) for impacts on tree growth (Acer rubrum and Betula nigra) on a disturbed site. Although a relatively large body of literature suggests beneficial impacts of inorganic fertilizers and organic materials, few studies have examined these six typical urban soil treatments in isolation for their effects on soil quality and tree growth in a controlled experiment. The primary research hypothesis was that due to more comprehensive and dramatic impacts on soil quality, the organic materials (COMP and WC) will have significantly greater impacts on tree growth compared to liquid-based treatments (FERT, ACT, and CBP). Because COMP is relatively more labile compared to WC, improvements in soil quality will be greater with COMP compared to WC.

\section{MATERIALS AND METHODS}

\section{Soil and Site Preparation}

In spring of 2007, an urban soil research plot (1.5 ha) was created in the research grounds of The Morton Arboretum in Lisle, DuPage County, Illinois, U.S. (N 41 ${ }^{\circ} 48^{\prime} 52.5^{\prime \prime}$ and $\left.\mathrm{W} 88^{\circ} 04^{\prime} 15^{\prime \prime}\right)$. The native soil (fine illitic, mesic, Oxyaquic Hapludalfs Ozaukee series) on site is moderately well drained, slowly permeable, and moderately deep to a densic contact with till. During site preparation, attempts were made to mimic the activities of a typical urban site development. The site preparation was performed when the soil was near field capacity in an attempt to maximize the impact of the disturbance. The topsoil $(0$ to $20 \mathrm{~cm}$ ) on the site was stripped with a bulldozer, and the underlying 
subsoil compacted (Caterpillar D4H Crawler Dozer, Caterpillar Inc., Peoria, Illinois, U.S.). A nominal depth of topsoil $(3 \mathrm{~cm})$ was replaced on site using a wheel loader (John Deere 444H, John Deere, Moline, Illinois, U.S.) and grader (Fiat Allis 65-B Grader, New Holland Agriculture, Torino, Italy).

Following the disturbance, soil descriptions were performed to assess the effect of the site disturbance on the soil. A soil pit $(2 \mathrm{~m}$ wide $\times 2.5 \mathrm{~m}$ deep) was dug bisecting the disturbed and adjacent undisturbed area and the soils were described. The most dramatic effects of the disturbance were concentrated in the top $20 \mathrm{~cm}$. Soil bulk density of the compacted zone ( 0 to $20 \mathrm{~cm}$ ) was increased to likely limiting values for root growth for this clay loam soil $\left(1.62 \mathrm{Mg} \mathrm{m}^{-3}\right)$, compared to $1.40 \mathrm{Mg} \mathrm{m}^{-3}$ for the clay loam in the adjacent undisturbed area. The disturbed profile was wetter throughout, with increased redoximorphic features deeper in the profile. The structure of the undisturbed Ap horizon was granular departing to subangular in the $\mathrm{E}$ and Bt horizons. The disturbed profile had platy and angular blocky soil structure in the top $20 \mathrm{~cm}$.

To assess the uniformity of the disturbance across the plot, 30 penetration resistance readings to a depth of $46 \mathrm{~cm}$ were measured across the plot at random locations and compared to ten measurements from the adjacent undisturbed area using a cone penetrometer (FieldScout SC-900 Soil Penetrometer, Spectrum Technologies, Inc., Plainfield, Illinois, U.S.). These measurements were performed within a three-hour period on $04 / 28 / 2008$. Mean penetration resistance in the top $46 \mathrm{~cm}$ in the disturbed area was $2.26 \pm 0.09 \mathrm{MPa}$, compared to $1.90 \pm 0.07 \mathrm{MPa}$ in the undisturbed area.

\section{Plant Materials}

A rectangular experimental grid with 120 square tree plots $(3.05 \mathrm{~m} \times 3.05 \mathrm{~m})$ and $1.53 \mathrm{~m}$ inter-plot space was laid out on the disturbed area. Sixty Betula nigra and sixty Acer rubrum branched liners (grafted top two-year-old and roots four years old), 1 to $1.5 \mathrm{~m}$ height, and 3 to $4 \mathrm{~cm}$ diameter, J. Frank Schmidt \& Sons, Co., Boring, Oregon, U.S.) were randomly assigned to plots. All Betula nigra trees died after planting and had to be replaced with new plantings. Tree planting was performed with a $0.45 \mathrm{~m}$ diameter auger mounted on a multi terrain loader (Caterpillar 277B, Caterpillar Inc., Peoria,
Illinois, U.S.). These two species were chosen for their ability to tolerate seasonal wetness on the site. Both exhibit chlorosis with typical urban conditions, including extreme soil $\mathrm{pH}$ and compaction. Birch is ectomycorrhizal and maple is endomycorrhizal. After trees were planted, the site was seeded with Kentucky bluegrass (Poa pratensis). Trees and lawn were irrigated during dry periods in the establishment year (2007). Following the establishment year treatment application began in the spring of 2008 .

\section{Treatments}

Treatments were applied May through October, annually, from 2008 through 2010. Treatments and application rates included 1) water control (NULL) at $840 \mathrm{~L} 100 \mathrm{~m}^{-2} \mathrm{yr}^{-1}$ (split evenly over five monthly applications); 2) aerated compost tea (ACT) at $840 \mathrm{~L}$ $100 \mathrm{~m}^{-2} \mathrm{yr}^{-1}$ (split evenly and applied with water over five monthly applications); 3) a commercial biological product (CBP) diluted with water at $840 \mathrm{~L} 100$ $\mathrm{m}^{-2} \mathrm{yr}^{-1}$ (applied in May and September with water alone in June, July, and August); 4) a NPK fertilizer (FERT) at $1.95 \mathrm{~kg} \mathrm{~N} 100 \mathrm{~m}^{-2} \mathrm{yr}^{-1}$ (applied with water in May and September and water alone applied in June, July, and August) (Smiley et al. 2002; ANSI 2004); 5) compost (COMP) at $2.5 \mathrm{~cm}$ as a top dressing (applied in May of each year); and 6) doubleground hardwood wood chip (WC) mulch to a 15 $\mathrm{cm}$ depth (applied in May of each year). Compost and mulch plots also received water at $840{\mathrm{~L} 100 \mathrm{~m}^{-2}}^{-2}$ $\mathrm{yr}^{-1}$ when other plots were treated. Treatment characterizations were performed and are listed in Table 1.

Aerated compost tea was made with a $946 \mathrm{~L}$ compost tea brewer (Geotea-250, Greater Earth Organics, Chilton, Wisconsin, U.S.). The brewer was filled with water and aerated for 24 hours prior to adding ingredients to de-gas any chlorine in water. After de-gassing, $8 \mathrm{~L}$ of compost was added to a mesh bag and placed in the brewer. The compost (Purple Cow Organics, Inc., Oconomowoc, Wisconsin, U.S.) contained $8,300 \mathrm{mg}$ bacteria $\mathrm{kg}^{-1}, 3,547 \mathrm{mg}$ fungi $\mathrm{kg}^{-1}$ (mean hyphae diameter of $3.0 \mu \mathrm{m}), 1,883$ flagellates $\mathrm{g}^{-1}, 1,459$ amoebae $\mathrm{g}^{-1}$, 1,134 ciliates $\mathrm{g}^{-1}$, and 10 nematodes $\mathrm{g}^{-1}$ (fluorescence and light microscopic analyses performed by Soil Foodweb, Inc., Corvallis, Oregon, U.S.). Additional ingredients in the brew included 750 $\mathrm{ml}$ of liquid humic acid, $700 \mathrm{ml}$ of soluble kelp, $500 \mathrm{ml}$ of fish hydrolysate, and $750 \mathrm{ml}$ of brown 
Table 1. Amounts of total N, Bray P, exchangeable $\mathrm{K}$, total $\mathrm{C}$, total bacteria, and total fungi added per year and the moisture, $\mathrm{pH}$, and microbial respiration rate of these treatments: water control (NULL), commercial biological product (CBP), aerated compost tea (ACT), NPK fertilizer (FERT), compost (COMP), and wood-chip mulch (WC).

\begin{tabular}{|c|c|c|c|c|c|c|}
\hline Response & NULL & $\mathrm{CBP}$ & $\mathrm{ACT}$ & FERT & COMP & WC \\
\hline Moisture (\%) & $\mathrm{n} / \mathrm{a}$ & $\mathrm{n} / \mathrm{a}$ & $\mathrm{n} / \mathrm{a}$ & $\mathrm{n} / \mathrm{a}$ & 26.2 & 9.7 \\
\hline $\mathrm{pH}(1: 1)$ & 6.61 & 7.33 & 8.10 & 7.34 & 7.60 & 5.91 \\
\hline Total N (kg $\left.100 \mathrm{~m}^{-2}\right)$ & $4.8 \mathrm{E}^{-5}$ & 0.0741 & 0.0773 & 1.95 & 0.385 & 0.527 \\
\hline Bray P (kg $\left.100 \mathrm{~m}^{-2}\right)$ & $6.1 \mathrm{E}^{-9}$ & $7.0 \mathrm{E}^{-5}$ & $1.9 \mathrm{E}^{-3}$ & 0.280 & 0.0688 & 0.0560 \\
\hline Exch. K (kg $\left.100 \mathrm{~m}^{-2}\right)$ & $1.2 \mathrm{E}^{-8}$ & $2.7 \mathrm{E}^{-5}$ & $3.4 \mathrm{E}^{-5}$ & 0.369 & 0.0343 & 0.0410 \\
\hline Total C (kg $\left.100 \mathrm{~m}^{-2}\right)$ & $1.1 \mathrm{E}^{-3}$ & 1.22 & 1.76 & 1.63 & 5.25 & 20.25 \\
\hline Micr. resp. $\left(\mathrm{mg} \mathrm{kg}^{-1} \mathrm{~d}^{-1}\right)$ & 1.50 & 19.6 & 18.8 & 11.2 & 26.6 & 30.6 \\
\hline Total bact. $\left(\mathrm{kg} 100 \mathrm{~m}^{-2}\right)$ & $6.1 \mathrm{E}^{-10}$ & 0.420 & 0.565 & $4.8 \mathrm{E}^{-5}$ & 8.22 & 4.05 \\
\hline Total fungi $\left(\mathrm{kg} 100 \mathrm{~m}^{-2}\right)$ & $6.1 \mathrm{E}^{-11}$ & $7.0 \mathrm{E}^{-3}$ & 0.011 & $6.4 \mathrm{E}^{-7}$ & 4.67 & 3.04 \\
\hline
\end{tabular}

rice powder. During the 24-hour brew cycle, dissolved oxygen, temperature, $\mathrm{pH}$, and electrical conductivity were measured every hour. Dissolved oxygen remained above $6 \mathrm{mg} \mathrm{kg}^{-1}$, with a mean value of $8.4 \mathrm{mg} \mathrm{kg}^{-1}$ throughout the brew cycle. Mean temperature, $\mathrm{pH}$, and electrical conductivity were $24^{\circ} \mathrm{C}, 8.1$, and $560 \mu \mathrm{S} \mathrm{cm}{ }^{-1}$, respectively. On average (18 brews) the ACT contained only a fraction of what was in the compost itself: 2,688 $\mathrm{mg}$ bacteria $\mathrm{kg}^{-1}$, $50 \mathrm{mg}$ fungi $\mathrm{kg}^{-1}$ (mean hyphae diameter of $3 \mu \mathrm{m}), 200$ flagellates $\mathrm{g}^{-1}, 140$ amoebae $\mathrm{g}^{-1}, 8$ ciliates $\mathrm{g}^{-1}$, and 0.1 nematodes $\mathrm{g}^{-1}$. Upon completion of brewing, the ACT concentrate was diluted at a ratio of 1:4 (1 part ACT concentrate to 4 parts water) and immediately applied to plots as a soil drench. Applications were performed in the morning and not during periods of full sun.

The commercial biological product (CBP) contained the following microbes: Bacillus azotofixans $\left(33,250 \mathrm{mg} \mathrm{kg}^{-1}\right)$, B. licheniformis $\left(33,250 \mathrm{mg} \mathrm{kg}^{-1}\right)$, B. megaterium $\left(33,250 \mathrm{mg} \mathrm{kg}^{-1}\right), B$. polymyxa $\left(33,250 \mathrm{mg} \mathrm{kg}^{-1}\right)$, B. subtilis $\left(33,250 \mathrm{mg} \mathrm{kg}^{-1}\right), B$. thuringinensis $\left(33,250 \mathrm{mg} \mathrm{kg}^{-1}\right)$, Streptomyces griseoviridis (665 mg kg-1), and Trichoderma harzianum $\left(3,325 \mathrm{mg} \mathrm{kg}^{-1}\right)$. The CBP also contained maltodextrin (48\%), yeast extract (5\%), soluble seaweed (13\%), humic acids derived from leonardite (17\%), precipitated silica $(8 \%)$, leonardite extract $(6 \%)$, and polyethylene glycol (3\%). The CBP was applied as a soil drench with water at $840 \mathrm{~L} 100 \mathrm{~m}^{-2} \mathrm{yr}^{-1}$.

The NPK fertilizer contained $30 \%$ elemental N (20\% water insoluble synthesized $\mathrm{N}$ and $10 \%$ watersoluble synthesized $\mathrm{N}$ ), $4.4 \%$ elemental $\mathrm{P}$ or $10 \%$ available phosphoric acid $\left(\mathrm{P}_{2} \mathrm{O}_{5}\right)$, and $5.8 \%$ elemental $\mathrm{K}$ or $7 \%$ soluble potash $\left(\mathrm{K}_{2} \mathrm{O}\right)$. The fertilizer $\mathrm{N}$ source is urea-formaldehyde, $\mathrm{P}$ source is monopotassium phosphate, and $\mathrm{K}$ source is monopotassium phosphate. The fertilizer was also applied as a soil drench.
The compost (Midwest Organics Recycling, McHenry, Illinois, U.S.) contained 4,698 mg bacteria $\mathrm{kg}^{-1}, 2,670 \mathrm{mg}$ fungi $\mathrm{kg}^{-1}$ (mean hyphae diameter of $3.0 \mu \mathrm{m}), 123,831$ flagellates $\mathrm{g}^{-1}, 5,756$ amoebae $\mathrm{g}^{-1}$, 123 ciliates $\mathrm{g}^{-1}$, and 2.82 nematodes $\mathrm{g}^{-1}$ (analyses performed by Soil Foodweb, Inc., Corvallis, Oregon, U.S.). The mulch was double-ground hardwood chips. Average chip size was $2 \mathrm{~cm}$ in length by 0.5 $\mathrm{cm}$ thick. The mulch contained 1,000 mg bacteria $\mathrm{kg}^{-1}, 750 \mathrm{mg}$ fungi $\mathrm{kg}^{-1}$ (mean hyphae diameter of $3.0 \mu \mathrm{m}), 1,900$ flagellates $\mathrm{g}^{-1}, 600$ amoebae g $^{-1}, 5$ ciliates $\mathrm{g}^{-1}$, and 0.5 nematodes $\mathrm{g}^{-1}$. Mulch was applied annually in May to a $15 \mathrm{~cm}$ depth. Compost was applied annually in May as a $2.5 \mathrm{~cm}$ topdressing.

\section{Soil Sampling and Characterization}

Soil bulk density (Db) was determined on $06 / 02 / 2011$. A $7.24 \mathrm{~cm}$ wide by $7.10 \mathrm{~cm}$ deep undisturbed core was extracted from each plot. Soil was sieved, homogenized, and dried in an oven for 48 hours at $105^{\circ} \mathrm{C}$. Material (roots, rock, etc.) greater than $2 \mathrm{~mm}$ was removed and its volume determined for bulk density corrections for non-soil material (Topp et al. 2008). On 10/06/2011, five $2.5 \mathrm{~cm}$ soil cores (0 to $15 \mathrm{~cm}$ depth) were collected at random points from the 120 plots and returned to the laboratory for characterization. In the laboratory, soil subsamples were weighed, dried for 24 hours at $105^{\circ} \mathrm{C}$, and reweighed to calculate gravimetric soil moisture (Topp et al. 2008). Soil $\mathrm{pH}$ was measured in 1:1 (soil:deionized) water pastes (Model Orion 5-Star, Thermo Fisher Scientific Inc., Waltham, Massachusetts, U.S.). Soil samples were extracted with $1 \mathrm{M}$ $\mathrm{NH}_{4} \mathrm{OAc}(\mathrm{pH}$ 7.0) for determination of potassium (K) via atomic adsorption spectroscopy (Model A5000, Perkin Elmer Inc., Waltham, Massachusetts, U.S.) (Schollenberger and Simon 1945). Phosphorus (P) was determined with the Bray P-1 extraction 
and analyzed colorimetrically at $882 \mathrm{~nm}$ on a spectrophotometer (Model UV mini 1240, Shidmadzu Inc., Kyoto, Japan) (Olsen and Sommers 1982). Total carbon $(\mathrm{C})$ and nitrogen $(\mathrm{N})$ were determined by automated dry combustion on a $\mathrm{CN}$ analyzer (Vario ELIII, Elementar Analysensysteme, Hanau, Germany) (Nelson and Sommers 1996). Loss on ignition at $360^{\circ} \mathrm{C}$ for six hours was used to determine the soil organic matter (SOM) content (Nelson and Sommers 1996). Microbial respiration (RES) was measured in 10 day dark incubations at $25^{\circ} \mathrm{C}$ with soils adjusted to $40 \%$ water-holding capacity with $0.25 \mathrm{M} \mathrm{NaOH}$ traps. Carbon dioxide sequestered in $\mathrm{NaOH}$ was precipitated with $0.5 \mathrm{M} \mathrm{BaCl}_{2}$ followed by $0.25 \mathrm{M} \mathrm{HCl}$ (standardized) titration to a phenolphthalein endpoint (Parkin et al. 1996).

\section{Tree Biomass}

Sixty trees were destructively sampled in spring of 2011 and the remaining sixty in the spring of 2013. During each sampling period, five blocks of 12 trees each were sampled, with each block containing the full complement of treatments and species combinations. The sampling period did not interact with the main effects of treatment or species for any of the biomass fractions; consequently growth is presented by combining data across the two sampling dates. For simplicity, change in tree biomass is presented as growth after five years of treatment even though sixty trees had four years of treatments and sixty trees had six years of treatments (Figure 1).

Trees were removed from the ground using a $0.9 \mathrm{~m}$ diameter tree spade (Optimal 880, Optimal-Vertrieb Optiz GmbH, Eysoelden, Germany) mounted on a multi terrain loader (Caterpillar 277B, Caterpillar Inc., Peoria, Illinois, U.S.). Soil was removed from rootballs using a pneumatic air tool (X-ST, Supersonic Air Knife, Inc., Allison Park, Pennsylvania, U.S.). Turf roots were removed by hand-sorting. Tree biomass fractions of fine roots ( $<2 \mathrm{~mm}$ diameter), medium roots $(2-5 \mathrm{~mm})$, coarse roots $(>5 \mathrm{~mm})$, stems and leaves were hand-sorted, washed, dried to constant moisture $\left(60^{\circ} \mathrm{C}\right.$ for one week), and weighed.

\section{Statistical Analyses}

The experiment was a randomized complete block design, with 120 total plots, two species, six treatments and ten replications. Data distributions were checked for normality using the Shapiro-

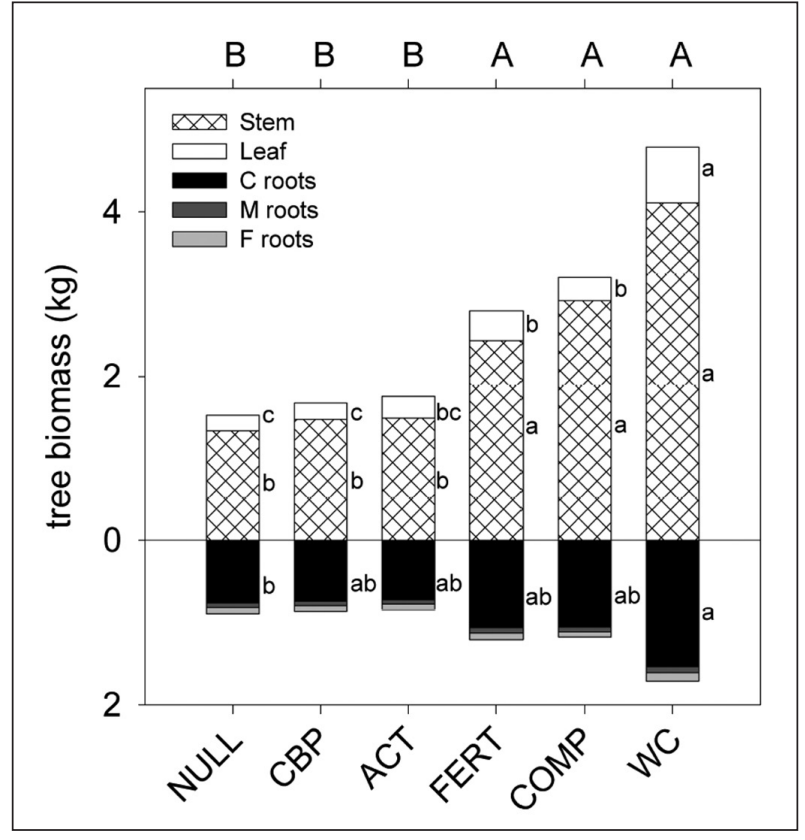

Figure 1. Stem, leaf, coarse, medium, and fine root biomass fractions of Acer rubrum and Betula nigra on a compacted urban soil plot receiving water control (NULL), commercial biological product (CBP), aerated compost tea (ACT), NPK fertilizer (FERT), wood chip mulch (WC), and compost (COMP) treatments for five consecutive years. Uppercase letters on top indicate significant differences among treatments in total biomass using Tukey's HSD test. Lowercase letters indicate differences among leaf, stem, and coarse root fractions. Differences were not significant for medium and fine root fractions. Each fraction is a mean of $\mathbf{2 0}$ trees.

Wilk W-test. Transformations of non-normal data were performed when necessary. Main effects and interactions were assessed with two-way repeated measures analysis of variance (ANOVA). Mean separations were carried out with the Tukey's HSD test. Pairwise correlations with Pearson productmoment were used to identify significant relationships among variables. Principal component analyses were used to establish which soil property explained most variance in the complete data set (Fox and Metla 2005). Significant differences were determined at the 95\% confidence level. Statistical analyses were conducted using SAS JMP 7.0 software (SAS Inc., Cary, North Carolina, U.S.).

\section{RESULTS AND DISCUSSION}

\section{Soil Responses}

All soil responses assessed in this research showed significant treatment effects and only microbial respiration (RES) showed a significant response 
to tree species (Table 2). Microbial respiration was significantly greater with Betula nigra (106.4 \pm 31.6 $\mathrm{mg} \mathrm{kg}^{-1} \mathrm{~d}^{-1}$ ) compared to Acer rubrum (91.8 \pm 28.2 $\left.\mathrm{mg} \mathrm{kg}^{-1} \mathrm{~d}^{-1}\right)$. The increase in microbial respiration is likely due to substrate decomposability. Nitrogen content of Betula nigra leaves $(2.10 \pm 0.47)$ was significantly greater than in Acer rubrum $(1.67 \pm 0.35)$ leaves. No significant treatment by species effects were detected for any of the soil responses.

Soil bulk density was significantly lower under WC compared to NULL (Figure 2). Soil moisture content was significantly greater with WC compared to FERT, ACT, CBP, and NULL. Soil moisture was also greater with COMP compared to FERT and
NULL. Soil organic matter was significantly greater with COMP compared to all other treatments. Soil organic matter under WC was greater than FERT, ACT, CBP, and NULL. Microbial respiration was significantly greater with COMP and WC compared to ACT, CBP, and NULL. Soil pH was significantly greater with COMP compared to FERT, ACT, CBP, and NULL. Soil N, P, and K was significantly greater with COMP compared to all other treatments. Soil $\mathrm{P}$ was significantly greater with FERT compared to ACT, CBP, and NULL. Soil $K$ was significantly greater with WC compared to CBP.

The overall effects of WC treatment on soil quality were to reduce bulk density by $10 \%$, increase soil

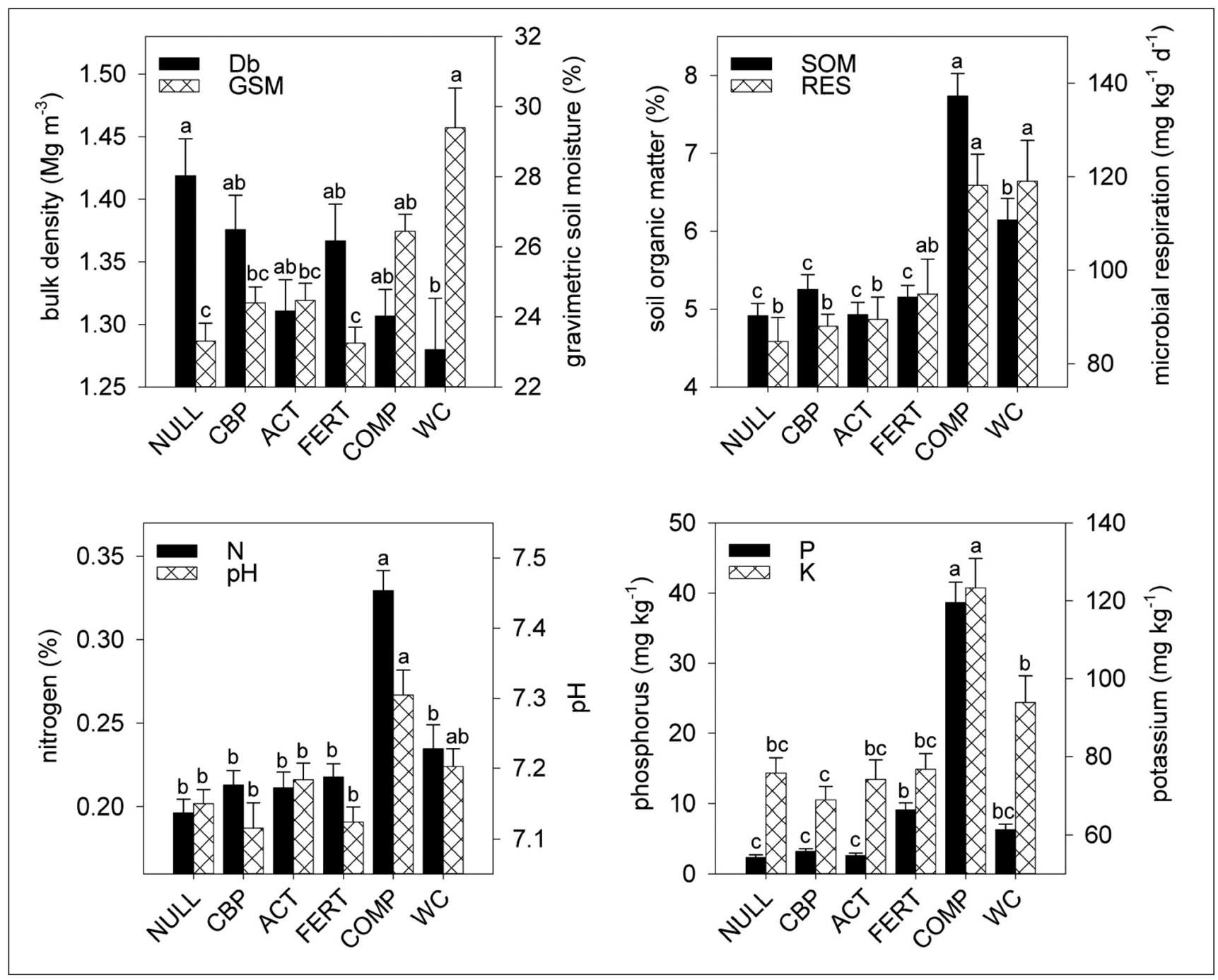

Figure 2. Soil bulk density, gravimetric soil moisture, soil organic matter, microbial respiration, $\mathrm{pH}$, and $\mathrm{N}$, $\mathrm{P}$, and $\mathrm{K}$ on a compacted urban soil plot receiving water control (NULL), commercial biological product (CBP), aerated compost tea (ACT), NPK fertilizer (FERT), wood-chip mulch (WC), and compost (COMP) treatments for five consecutive years. Lowercase letters indicate significant differences among treatments using Tukey's HSD test. Each bar is a mean of 20 plots. 
Table 2. Prob > F values for effect tests of treatment, species, and treatment*species using ANOVA standard least squares models for soil bulk density, soil moisture, $\mathrm{pH}, \mathrm{N}$, $\mathrm{P}, \mathrm{K}$, soil organic matter, and microbial respiration.

\begin{tabular}{llll}
\hline Soil response & Treatment & Species & $\mathrm{Tr}^{\star} \mathrm{Sp}$ \\
\hline Bulk density $\left(\mathrm{Mg} \mathrm{m}^{-3}\right)$ & 0.0116 & 0.7174 & 0.4962 \\
Gravimetric soil moisture $(\%)$ & $<0.0001$ & 0.0590 & 0.9538 \\
$\mathrm{pH}(1: 1)$ & $<0.0001$ & 0.8827 & 0.3997 \\
Total N $(\%)$ & $<0.0001$ & 0.3304 & 0.9330 \\
Bray P $\left(\mathrm{mg} \mathrm{kg}^{-1}\right)$ & $<0.0001$ & 0.9667 & 0.9917 \\
Exchangeable K $\left(\mathrm{mg} \mathrm{kg}^{-1}\right)$ & $<0.0001$ & 0.8466 & 0.8702 \\
Soil organic matter $(\%)$ & $<0.0001$ & 0.9151 & 0.1367 \\
Microbial respiration $\left(\mathrm{mg} \mathrm{kg}^{-1} \mathrm{~d}^{-1}\right)$ & $<0.0001$ & 0.0025 & 0.6508 \\
\hline
\end{tabular}

moisture by $26 \%$, increase SOM by $25 \%$, increase RES by $33 \%$, and increase $\mathrm{K}$ by $24 \%$. The COMP treatment increased soil moisture $+13 \%, \mathrm{SOM}+57 \%$, RES 39\%, $\mathrm{N}+68 \%, \mathrm{P}+1544 \%$, and $\mathrm{K}+64 \%$. Relative to the control, the FERT treatment only impacted soil $\mathrm{P}$, which increased $286 \%$. No differences were observed for these eight soil properties between the NULL treatment and ACT or CBP treatment.

Both WC and COMP appear to be the most effective treatments at improving soil quality. The WC treatment tended to be more effective at improving soil physical condition (density and moisture), whereas the COMP treatment better improved soil biochemistry (SOM, RES, N, P, and K). It was expected that soil moisture would be greatest with the WC treatment. Wood-chip mulches would limit evaporation and also limit water uptake by competing vegetation (Watson 1988).

Compost is a source of labile organic matter and nutrients. It was expected and found that the COMP treatment would most increase organic matter and stimulate microbial activity. These increases in SOM and microbial activity appeared to, in-turn increase soil nutrient supplies of N, P, and K (Scharenbroch et al. 2013). The increases in soil $\mathrm{P}$ with COMP are concerning given the potential for $\mathrm{P}$ pollution of aquatic ecosystems (Carpenter et al. 1998). Precautions should be taken when using composts in urban landscapes to minimize runoff and erosion, which are major pathways of $\mathrm{P}$ loss to surface waters.

The observed decrease in bulk density with WC treatment, and not with COMP treatment, was somewhat surprising. Biological activity is an important driver of soil aggregation, which would work to reduce bulk density and alleviate soil compaction. The WC treatment increased microbial respiration but also had the most significant impact on tree growth. Increases in soil moisture with the WC treatment may also have been important for facilitating root growth through these compacted urban soils and thereby increasing the extent of soil that roots and microbes would access. Together, increased microbial and tree root growth likely contributed to the observed decreased bulk density.

Soil $\mathrm{pH}$ was expected to decrease with COMP and FERT treatments due to the $\mathrm{pH}$-lowering effects of respiration and $\mathrm{N}$ mineralization (Sikora and Yakovchenko 1996). However, soil $\mathrm{pH}$ increased with compost and it may be that the compost increased base saturation by increasing Al complexation (Van den Berghe and Hue 1999).

\section{Tree Growth Responses}

Significant treatment effects were detected for total tree biomass, total shoot biomass, total root biomass, stem biomass, leaf biomass, and coarse root biomass (Table 3). Treatment effects were not significant for medium and fine root biomass. Species effects were significant for all tree responses except fine root biomass, and the treatment by species effect was only significant for leaf biomass.

Table 3. Prob > F values for effect tests of treatment, species, and treatment*species using ANOVA standard least squares models for tree biomass fractions.

\begin{tabular}{llll}
\hline Tree response & Treatment & Species & $\operatorname{Tr}^{\star} \mathrm{Sp}$ \\
\hline Total biomass $(\mathrm{g})$ & $<0.0001$ & $<0.0001$ & 0.1401 \\
Total shoot biomass $(\mathrm{g})$ & $<0.0001$ & $<0.0001$ & 0.0319 \\
Leaf biomass $(\mathrm{g})$ & $<0.0001$ & $<0.0001$ & $<0.0001$ \\
Stem biomass $(\mathrm{g})$ & $<0.0001$ & $<0.0001$ & 0.1917 \\
Total root biomass $(\mathrm{g})$ & $<0.0001$ & $<0.0001$ & 0.8981 \\
Coarse root biomass $(>5 \mathrm{~mm})(\mathrm{g})$ & 0.0006 & $<0.0001$ & 0.7934 \\
Medium root biomass $(2-5 \mathrm{~mm})(\mathrm{g})$ & 0.1544 & $<0.0001$ & 0.6990 \\
Fine root biomass $(<2 \mathrm{~mm})(\mathrm{g})$ & 0.2393 & 0.6841 & 0.2955 \\
\hline
\end{tabular}

Given the minimal treatment by species effects, main treatment effects were examined by combining both species. Total tree biomass and total stem biomass were significantly greater with WC, COMP, and FERT compared to ACT, CBP, and NULL (Figure 1). Total stem biomass was also significantly greater with WC compared to FERT. Leaf biomass was significantly greater with WC compared all other treatments, and leaf biomass was greater with FERT and COMP compared to CBP and NULL. Stem biomass was significantly greater with WC, COMP, and FERT compared to ACT, CBP, and NULL. Coarse root biomass was significantly greater with 
WC compared to NULL. No significant differences were detected for medium and fine root biomass.

After five years in this compacted urban soil, total tree biomass was $170 \%$ greater with WC compared to control trees. Trees that received COMP and FERT grew $82 \%$ and $69 \%$, respectively, more total biomass compared to control trees. These results provide strong evidence for the beneficial impacts of WC, COMP, and FERT for increasing tree growth in compacted urban soils. Many studies have identified positive improvements in tree growth with organic amendments and these findings have been summarized in two relatively recent literature reviews by Chalker-Scott (2007) and Scharenbroch (2009). The potential mechanisms for these observed increases in tree growth are presented and discussed in the preceding section of this paper. Trees that received ACT and CBP treatment did not differ in total biomass or any specific biomass fraction compared to control trees. These results provide evidence for the ineffectiveness of these treatments to stimulate tree growth in this compacted urban soil. Similar ineffectiveness of compost teas to stimulate tree growth in urban soils has been reported previously (Scharenbroch 2013; Scharenbroch et al. 2013).

Researchers unexpectedly found that medium and fine root biomass did not respond in a similar fashion to coarse root biomass. Coarse roots grow by producing wood, like stem tissue; whereas, fine root growth is largely primary growth and more influenced by soil conditions (Shigo 1999). It is possible that these treatments did not impact fine and medium root growth, but we feel this is unlikely given the significant responses in soil properties we observed. Soil responses would suggest that fine and medium root growth are equally or more responsive to these treatments than coarse roots.

Relative to coarse roots, fine roots have a very low dry density. It is possible that these small differences in mass with fine and medium roots were not detected in statistical testing. In addition, roots outside of the tree-spaded hole were not included in this assessment. A subsampling of the soil outside of the hole on 13 plots revealed that on average $0.054 \pm 0.041 \mathrm{~kg}$ of root biomass was not sampled, which is only $1 \%-2 \%$ of the total biomass measured on the trees. It is recognized that the estimates of root biomass may be conservative due to sampling methodology; however, this underes- timation is not likely to impact the main focus of the research, which was to examine the effects of these treatments on tree growth and soil quality.

Another plausible explanation is that the sampling methodology masked treatment responses by damaging and removing fine and medium roots. To determine root biomass, trees were dug with a tree spade, and an air knife was used to remove the soil from the root balls. In removing the soil with the air knife, the fine and medium roots may have been removed. Attempts were made to minimize root damage during this process but fine and medium roots were visibly removed and it was not possible to quantify this effect. However, researchers have no reason to suspect that the damage was unequal across treatments and/or species.

\section{Tree Growth Modeling}

Linear regressions among soil and tree responses showed significant and positive relationships with tree biomass and SOM, GSM, RES, N, P, and K (Table 4). A significant and negative relationship existed between bulk density and tree biomass. Soil $\mathrm{pH}$ was not significantly correlated with tree biomass. Although significant, correlations among soil and tree responses were generally weak $\left(\mathrm{r}^{2}<0.18\right)$. Of the soil responses, SOM was most strongly correlated with tree biomass.

Stepwise regression modeling did not improve correlation with tree biomass. Forward, backward, and mixed modeling approaches all identified SOM as the sole and most important predictor of tree biomass. A principal component analysis revealed that the first principal component explained $51.4 \%$ of the variation in soil responses. The first principal component was strongly correlated with SOM (Eigenvector score of 0.4051). Soil organic matter was also significantly correlated with all other soil properties (Table 5).

All models suggest SOM to be the most important soil indicator of tree growth. Soil organic matter is a critical component of soil quality as it integrates physical, chemical, and biological properties (Doran and Parkin 1994). Soil organic matter is composed of living and dead flora and fauna. Soil organic matter is relatively lightweight, has a high surface area, and contains nutrients and microbes. Soil organic matter is known to improve biological condition of soil by increasing microbial 
activity, which in turn leads to an increase in nutrient availability and also biological aggregation (Tisdall and Oades 1982; Carter 2002). Soil organic matter is also known to impact chemical properties such as pH (Gerritse and Van Driel 1984). Reductions in compactibility and soil bulk densities (Soane 1990) and increases in soil water availability (Hudson 1994) are known improvements in soil physical properties with soil organic matter.

\section{Management Implications}

Soil management for urban trees most often focuses on fertilization. Increased tree growth was observed with FERT, but no changes to soil properties were observed with this treatment. Nutrients in the FERT treatment may have been directly taken up by the tree and/or turf grass, but may also have been lost to environment through volatilization or leaching (Follett 1981; Finck 1982). This research found no evidence that the FERT treatment worked to improve soil quality on this compacted plot. Current best management practices for urban trees describe the appropriate rates and application methods for $\mathrm{N}$ fertilization but do not consider overall soil quality as a management target (Smiley et al. 2013).

These results suggest that fertility is only a component of soil quality with influence on tree growth in compacted urban soils. These results point toward managing soil organic matter as an effective strategy in remediating urban soil quality for tree growth. Furthermore, if soil organic matter is a management target, these results show that effective treatments for increasing soil organic matter are COMP and WC. Management goals may often dictate the type of organic amendment to use. For instance, if the goal is to build SOM quickly and supply nutrients, relatively labile organic materials (i.e., $\mathrm{C} / \mathrm{N}$ ratio $<25$ ), like the compost used in this study, might be the preferred amendment. On the other hand if the goal is to increase soil water and improve soil structure, more recalcitrant organic materials (i.e., $\mathrm{C} / \mathrm{N}$ ratio $>25$ ), such as wood chips, may be more appropriate.

Similar to inorganic fertilization, management recommendations can be developed for organic materials to attain target nutrient release levels. Many agriculture extension stations have developed rates and calculators for applying organic materials to meet plant nutrient demands (e.g., Organic Fertilizer and Cover Crop Calculator 2014). The potential $\mathrm{N}$ release from compost can easily be calculated with dry weight, the $\mathrm{N}$ content and an estimate of the plant available $\mathrm{N}$ (PAN) released annually from the compost (Equation 1).

[1] $\quad \mathrm{kg} \mathrm{N} \mathrm{yr}^{-1}=$ [mass of compost $(\mathrm{kg}) *$ total $\mathrm{N}(\%)$ * PAN (\%)]

For example, the ANSI Standard's clause for tree fertilization suggests a rate of $1 \mathrm{~kg} \mathrm{~N} 100 \mathrm{~m}^{-2}$ $\mathrm{y}^{-1}$. Total $\mathrm{N}$ contents of composted materials tend to range from $1 \%-3 \%$ with PAN ranging from $5 \%-20 \%$. Compost $(500 \mathrm{~kg}$ ) with $2 \%$ total $\mathrm{N}$ and

Table 4. Slope, intercept, $\mathrm{r}^{2}$, and Prob > F values for linear fit models of soil properties to total tree biomass.

\begin{tabular}{|c|c|c|c|c|}
\hline Fit to tree biomass (g) & Slope & Intercept & $\mathrm{r}^{2}$ & Prob $>$ F \\
\hline Bulk density $\left(\mathrm{Mg} \mathrm{m}^{-3}\right)$ & -5.03 & 10.49 & 0.0904 & 0.0008 \\
\hline Gravimetric soil moisture (\%) & 0.23 & -2.02 & 0.1216 & $<0.0001$ \\
\hline $\mathrm{pH}(1: 1)$ & 2.47 & -13.98 & 0.0213 & 0.1119 \\
\hline Total N (\%) & 10.91 & 1.19 & 0.0899 & 0.0009 \\
\hline Bray P (mg kg-1) & 0.04 & 3.36 & 0.0505 & 0.0136 \\
\hline Exchangeable K $\left(\mathrm{mg} \mathrm{kg}^{-1}\right)$ & 0.03 & 1.59 & 0.1077 & 0.0003 \\
\hline Soil organic matter (\%) & 0.71 & -0.30 & 0.1780 & $<0.0001$ \\
\hline Microbial respiration $\left(\mathrm{mg} \mathrm{kg}^{-1} \mathrm{~d}^{-1}\right)$ & 0.02 & 1.85 & 0.0644 & 0.0052 \\
\hline
\end{tabular}

Table 5. Slope, intercept, $\mathrm{r}^{2}$, and Prob > F values for linear fit models of soil properties to soil organic matter.

\begin{tabular}{|c|c|c|c|c|}
\hline Fit to soil organic matter (\%) & Slope & Intercept & $\mathrm{r}^{2}$ & Prob $>$ F \\
\hline Bulk density $\left(\mathrm{Mg} \mathrm{m}^{-3}\right)$ & -4.31 & 11.48 & 0.1887 & $<0.0001$ \\
\hline Gravimetric soil moisture (\%) & 0.18 & 1.04 & 0.2252 & $<0.0001$ \\
\hline $\mathrm{pH}(1: 1)$ & 2.50 & -12.23 & 0.0617 & 0.0062 \\
\hline Total N (\%) & 15.12 & 2.15 & 0.4896 & $<0.0001$ \\
\hline Bray P $\left(\mathrm{mg} \mathrm{kg}^{-1}\right)$ & 0.07 & 4.98 & 0.5023 & $<0.0001$ \\
\hline Exchangeable $\mathrm{K}\left(\mathrm{mg} \mathrm{kg}^{-1}\right)$ & 0.03 & 3.40 & 0.3436 & $<0.0001$ \\
\hline Microbial respiration $\left(\mathrm{mg} \mathrm{kg}^{-1} \mathrm{~d}^{-1}\right)$ & 0.02 & 4.01 & 0.1308 & $<0.0001$ \\
\hline
\end{tabular}


$10 \%$ PAN would release $1 \mathrm{~kg}$ of $\mathrm{N} \mathrm{yr}^{-1}$, so this compost could be applied over $100 \mathrm{~m}^{2}$ to meet the ANSI clause for $\mathrm{N}$ application rate. Assuming a compost density of $500 \mathrm{~kg} \mathrm{~m}^{-3}$, this would be $1 \mathrm{~m}^{3}$ of compost.

In addition to the improvements in overall soil quality and tree growth observed in this research with organic materials, there are many environmental reasons to favor organic materials to inorganic fertilizers (Follett et al. 1981; Finck 1982). Nutrients in organic amendments are less likely to leach, run off, or volatilize compared to nutrients in inorganic fertilizers. Because organic materials tend to release nutrients more slowly, less consideration is required for matching application to plant demands. Organic amendments also provide additional nutrients (e.g., manganese, zinc, sulfur) that are often not included in inorganic fertilizers. Many organic amendments are created from residuals that would potentially enter landfills. Fossil fuel consumption is required to make and transport inorganic fertilizers-albeit, transportation of organic materials also requires fossil fuels (Jenssen and Kongshaug 2003). Long-term fertilization with inorganic $\mathrm{N}$ has been found to decrease soil $\mathrm{C}$ storage, whereas, organic materials tend to increase soil organic matter and C storage (Khan et al. 2007).

Soil and tree properties were not significantly impacted by ACT or CBP compared to NULL controls. Nutrients added per year by ACT and CBP

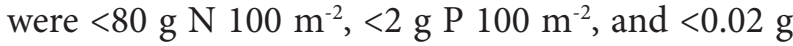
$\mathrm{K} 100 \mathrm{~m}^{-2}$ (Table 1). Conversely, amounts of N, P, and $\mathrm{K}$ added with COMP and WC were 0.4 and 0.5 $\mathrm{kg} \mathrm{N} 100 \mathrm{~m}^{-2} \mathrm{y}^{-1}, 0.07$ and $0.06 \mathrm{~kg} \mathrm{P} 100 \mathrm{~m}^{-2} \mathrm{y}^{-1}$, and 0.03 to $0.04 \mathrm{~kg} \mathrm{~K} 100 \mathrm{~m}^{-2} \mathrm{y}^{-1}$, respectively. Nutrients in COMP and WC were magnitudes greater than added in ACT and CBP. Total microbial biomass added per year with CBP and ACT was 0.427 and $0.576 \mathrm{~kg} 100 \mathrm{~m}^{-2}$ for CBP and ACT, respectively. On average, the total soil microbial biomass levels for these soils are $33.5 \mathrm{~kg} 100 \mathrm{~m}^{-2}$, which is 79 times and 58 times greater than the microbial biomass added per year in CBP and ACT. To match the existing soil microbial biomass levels, concentrated ACT

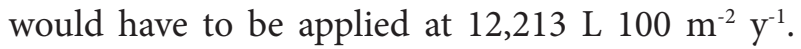
In comparison, the total microbial biomass added per year in COMP treatment was $12.9 \mathrm{~kg} 100 \mathrm{~m}^{-2}$, or $40 \%$ of the existing soil microbial biomass level.

The annual cost of these treatments on a per tree basis was computed (Table 6). Labor costs comprised the largest portion of the budget for all treatments. Total costs were greatest for ACT followed by WC, FERT, COMP, CBP, and lastly NULL. The amount of biomass gained per tree per year was greatest for WC and lowest for the NULL treatment. The most efficient $\left(\$ \mathrm{~g}^{-1}\right)$ treatments were $\mathrm{WC}$, COMP, and NULL. As a result of the large initial investment in a compost tea brewer, large amount of labor, and relatively low growth response, ACT was highly inefficient compared to the other treatments.

\section{CONCLUSION}

Compost topdressings and wood chip mulches should be used as soil management techniques for trees growing in compacted urban soils. These results confirm the hypothesis that greater improvements in soil quality and tree growth would be observed with solid organic materials (COMP and WC) compared to liquid-based treatments (ACT and CBP). The research demonstrates that COMP and WC are effective and cost-efficient alternatives to inorganic fertilizer for improving soil quality and increasing tree growth in compacted urban soil. It is reasonable to expect that combining wood chips and composts may have even greater benefit for improving soil quality for urban trees. Future research should examine the effectiveness of combining these and other organic materials in attempts to mimic the organic and A-horizons

Table 6. Annual costs for materials, equipment, and labor, and growth and efficiency per tree for water control (NULL), commercial biological product (CBP), aerated compost tea (ACT), NPK fertilizer (FERT), compost (COMP), and wood-chip mulch (WC).

\begin{tabular}{|c|c|c|c|c|c|c|}
\hline Treatment & NULL & CBP & ACT & FERT & COMP & WC \\
\hline Materials (\$ tree $\left.{ }^{-1}\right)$ & 0.0 & 3.5 & 7.5 & 6.5 & 3.0 & 10.0 \\
\hline Equipment $\left(\$\right.$ tree $\left.^{-1}\right)$ & 0.5 & 3.5 & 28.5 & 3.5 & 1.0 & 1.0 \\
\hline Labor $\left(\$\right.$ tree $\left.^{-1}\right)$ & 7.5 & 11.3 & 30.0 & 11.3 & 15.0 & 15.0 \\
\hline Total cost $\left(\$\right.$ tree $\left.^{-1}\right)$ & 8.0 & 18.3 & 66.0 & 21.3 & 19.0 & 26.0 \\
\hline Growth (g tree $\left.{ }^{-1}\right)$ & 22.8 & 23.9 & 24.1 & 38.7 & 41.5 & 61.3 \\
\hline Efficiency $\left(\$ \mathrm{~g}^{-1}\right)$ & 0.35 & 0.77 & 2.74 & 0.55 & 0.46 & 0.42 \\
\hline
\end{tabular}


found in temperate forest soils. Future research must also consider the impacts of these organic materials on tree health, which does not necessarily have a positive linear relationship to tree growth.

Acknowledgments. Funding for this research was provided by the Tree Research and Education Endowment (TREE) Fund Hyland R. Johns grant (07-HJ-01) and The Morton Arboretum Endowment. The trees in this research were donated by J. Frank Schmidt \& Sons. We acknowledge and thank Research Assistants (Michelle Catania, Angela Hewitt, Marvin Lo and Doug Johnston) and also the many volunteers and student interns in The Morton Arboretum Soil Science Laboratory and Root Biology Laboratory for their work on this research.

\section{LITERATURE CITED}

American National Standards Institute (ANSI). 2004. American National Standard for Tree Care Operations - Tree, Shrub, and Other Woody Plant Maintenance - Standard Practices (Fertilization) (A300, Part 2). Tree Care Industry Association, Manchester, New Hampshire, U.S.

Carpenter, S.R., N.F. Caraco, D.L. Correll, R.W., Howarth, A.N. Sharpley, and V.H. Smith 1998. Nonpoint pollution of surface waters with phosphorus and nitrogen. Ecological Applications 8:559-568.

Carter, M.R. 2002. Soil quality for sustainable land management: Organic matter and aggregation interactions that maintain soil functions. Agronomy Journal 94:38-47.

Chalker-Scott, L. 2007. Impact of mulches on landscape plants and the environment - A review. Journal of Environmental Horticulture 25:239-249.

Day, S.D., E.P. Wiseman, S.B. Dickinson, and R.J. Harris. 2010. Contemporary concepts of root system architecture of urban trees. Arboriculture \& Urban Forestry 36:149-159.

Doran, J.W., and T.B. Parkin. 1994. Defining and assessing soil quality. pp. 3-21. In: J.W. Doran et al. (Ed.). Defining Soil Quality for a Sustainable Environment. SSSA Spec. Publ. No. 35, Soil Science Society of America, Inc. and American Society of Agronomy, Inc., Madison, Wisconsin, U.S.

Driscoll, C.T., D. Whitall, J. Aber, E. Boyer, M. Castro, C. Cronan, C.L. Goodale, P. Groffman, C. Hopkinson, K. Lambert, G. Lawrence, and S. Ollinger. 2003. Nitrogen pollution in the Northeastern United States: Sources, effects, and management options. BioScience 53:357-374.

Duffy, B., C. Sarreal, R. Subbarao, and L. Stanker. 2004. Effect of molasses on regrowth of E. coli O157:H7 and Salmonella in compost teas. Compost Science and Utilization 12:93-96.

Finck, A. 1982. Fertilizers and Fertilization. Introduction and Practical Guide to Crop Fertilization. Verlag Chemie, Deerfield Beach, Florida, U.S.

Follett, R.H., L.S. Murphy, and R.L. Donahue. 1981. Fertilizers and Soil Amendments. Prentice Hall, Inc. New Jersey, U.S.

Fox, G.A., and R. Metla. 2005. Soil property analysis using principal components analysis, soil line, and regression models. Soil Science Society of America Journal 69:1782-1788.
Gerritse, R.G., and W. Van Driel. 1984. The relationship between adsorption of trace metals, organic matter, and $\mathrm{pH}$ in temperate soils. Journal of Environmental Quality 13:197-204.

Herms, D.A., and W.J. Mattson. 1992. The dilemma of plants: To grow or defend. Quarterly Review of Biology. 67:283-335.

Hudson, B.D. 1994. Soil organic matter and available water capacity. Journal of Soil and Water Conservation 49:189-194.

Ingham, E. 2003a. Compost Tea Brewing Manual. Soil Foodweb, Inc., Corvallis, Oregon, U.S.

Ingham, E. 2003b. Compost tea: Promises and practicalities. Acres $33: 1-5$.

Ingham, E. 2004. Compost Tea Quality: Light Microscopic Methods. Soil Foodweb, Inc., Corvallis, Oregon, U.S.

Jenssen, T.K., and G. Kongshaug. 2003. Energy consumption and greenhouse gas emissions in fertilizer production. Proceedings 509 from International Fertilization Society. York, UK.

Khan, S.A., R.L. Mulvaney, and C.W. Boast. 2007. The myth of nitrogen fertilization for soil carbon sequestration. Journal of Environmental Quality 36:1821-1832.

Larkin, R.P. 2008. Relative effects of biological amendments and crop rotations on soil microbial communities and soilborne diseases of potato. Soil Biology and Biochemistry 40:1341-1351.

Lowenfels, J., and W. Lewis. 2007. Teaming with Microbes: A Gardener's Guide to the Soil Food Web. Timber Press, Portland, Oregon, U.S.

Mitsch, W.J., J.W. Day Jr., J.W. Gilliam, P.M. Groffman, D.L. Hey, G.W. Randall, and N. Wang. 2001. Reducing nitrogen loading to the Gulf of Mexico from the Mississippi River basin: Strategies to counter a persistent ecological problem. BioScience 51:373-388.

Mulvaney, R.L., S.A. Khan, and T.R. Ellsworth. 2009. Synthetic nitrogen fertilizers deplete soil nitrogen: a global dilemma for sustainable cereal production. Journal of Environmental Quality 38:2295-2314.

National Organic Standards Board (NOSB) 2004. Compost Tea Task Force Report. 09/04/2010. <www.ams.usda.gov/nosb/ archives/crop/recommendations/html>

National Organic Standards Board (NOSB). 2002. Compost Task Force Recommendation. 09/04/2010. <www.ams.usda.gov/ nosb/archives/crop/recommendations/html>

Nelson, D.W., and L.E. Sommers. 1996. Total carbon, organic carbon, and organic matter. In: D.L. Sparks et al. (Eds.). Methods of Soil Analysis. Part 3. Chemical Methods. Soil Science Society of America. Madison, Wisconsin. pp. 961-1010.

Olsen, S.R., and L.E. Sommers. 1982. Phosphorus. In: A.L. Page et al. (Eds.). Methods of Soil Analysis Part 2. Soil Science Society of America. Madison, Wisconsin. pp. 403-430.

Organic Fertilizer and Cover Crop Calculator. 2014. Accessed 02/07/2014. <http://smallfarms.oregonstate.edu/calculator>

Parkin, T.B., J.W. Doran, and E. Franco-Viscaino. 1996. Field and laboratory tests of soil respiration. Potentially mineralizable nitrogen as an indicator of biologically active soil nitrogen. In: Doran, J.W., and A.J. Jones (Eds.). Methods for Assessing Soil Quality. Soil Science Society of America, no. 49. Madison, Wisconsin. pp. 231-246.

Percival, G.C., and S. Barnes. 2005. The influence of calcium and nitrogen fertilization on the freezing and salinity tolerance of two urban tree species. Journal of Arboriculture 31:10-20. 
Saebo, A., and F. Ferrini. 2006. The use of compost in urban green areas - A review for practical application. Urban Forestry \& Urban Greening 4:159-160.

Scharenbroch, B.C. 2009. A meta-analysis of studies published in Arboriculture \& Urban Forestry relating to organic materials and impacts on soil, tree, and environmental properties. Arboriculture \& Urban Forestry 35:221-231.

Scharenbroch, B.C. 2013. Impacts of aerated compost tea on containerized Acer saccharum and Quercus macrocarpa saplings and soil properties in sand, uncompacted loam, and loam soils. HortScience 48:625-632.

Scharenbroch, B.C., E. Meza, M. Catania and K. Fite. 2013. Biochar and biosolids increase tree growth and improve soil quality for urban landscapes. Journal of Environmental Quality 42:13721385.

Scharenbroch, B.C., M. Catania, W. Treasurer, and V. Brand. 2011. Lab assays on the effects of aerated compost tea and fertilization on soil biochemical properties and denitrification in $\mathrm{A}$ and $\mathrm{Bt}$ horizon soils. Arboriculture \& Urban Forestry 37:269-276.

Scheuerell, S.J., and W.F. Mahaffee. 2004. Compost tea as a container medium drench for suppressing seedling damping off caused by Pythium ultimum. Phytopathology 94:1156-1163.

Scheuerell S.J., and W.F. Mahaffee. 2006. Variability associated with suppression of gray mold (Botrytis cinerea) on geranium by foliar applications of nonaerated and aerated compost teas. Plant Disease 90:1201-1208.

Schollenberger, C.J., and R.H. Simon. 1945. Determination of exchange capacity and exchangeable bases in soils - Ammonium acetate method. Soil Science 59:13-24.

Segarra, G., M. Reis, E. Casanova, and M.I. Trillas. 2009. Control of powdery mildew (Erysiphe polygoni) in tomato by foliar applications of compost tea. Journal of Plant Pathology 91:683-689.

Shigo, A.L. 1999. A new tree biology: Facts, photos, and philosophies on trees and their problems and proper care, 9th Edition. Shigo and Trees Associates, Durham, New Hampshire, U.S.

Sikora, L.J., and V. Yakovchenko. 1996. Soil organic matter mineralization after compost amendment. Soil Science Society of America Journal 60:1401-1404.

Smiley, E.T., S. Lilly, and P. Kelsey. 2002. Best management practices: Tree and shrub fertilization. International Society of Arboriculture, Champaign, Illinois, U.S.

Smiley, E.T., S.J. Lilly, and L. Werner. 2013. Best Management Practices: Tree and shrub fertilization, third edition. International Society of Arboriculture, Champaign, Illinois.

Soane, B.D. 1990. The role of organic matter in soil compactibility: A review of some practical aspects. Soil and Tillage Research 16:179-201.

Soldat, D.J., and A.M. Petrovic. 2008. The fate and transport of phosphorus in the turfgrass ecosystems. Crop Science 48:2051-2065.

Struve, D.K. 2002. A review of shade tree fertilization research in the United States. Journal of Arboriculture 28:252-263.

Tisdall, J.M., and J. Oades, J. 1982. Organic matter and water-stable aggregates in soils. Journal of Soil Science 33:141-163.

Topp, G.C., G.W. Parkin, and T.P.A. Ferre. 2008 Soil water content. In: M.R. Carter and E.G. Gregorich (Eds.). Soil sampling and methods of analysis. Canadian Society of Soil Science. CRC Press, Boca Raton, Florida, U.S. pp. 939-962.

Unger, P.W., and T.C. Kaspar. 1994. Soil compaction and root growth: A review. Agronomy Journal 86:759-766. van de Werken, H. 1981. Fertilization and other factors enhancing the growth rate of young shade trees. Journal of Arboriculture 7:33-37.

Van den Berghe, C.H., and N.V. Hue. 1999. Liming potential of composts applied to an acid oxisol in Burundi. Compost Science Utilization 7:40-46.

Vitousek, P.M., J.D. Aber, R.W. Howarth, G.E. Likens, P.A. Matson, D.W. Schindler, W.H. Schlesinger, and D.G. Tilman. 1997. Human alteration of the global nitrogen cycle: Sources and consequences. Ecological Applications 7:737-750.

Watson, G.W. 1988. Organic mulch and grass competition influence tree root development. Journal of Arboriculture 14:200-203.

Watson, G.W. 1994. Root growth response to fertilizers. Journal of Arboriculture 20(1):4-8.

Bryant C. Scharenbroch (corresponding author)

The Morton Arboretum

4100 Illinois Route 53

Lisle, Illinois 60532-1293, U.S.

BScharenbroch@mortonarb.org

Gary W. Watson

The Morton Arboretum

4100 Illinois Route 53

Lisle, Illinois 60532-1293, U.S. 
Zusammenfassung. Das Baumwachstum wird negativ durch die Entfernung von Oberboden und die Verdichtung des Unterbodens im Verbindung mit der Standortentwicklung in urbanen Landschaften beeinflusst. Es wurde ein Forschungsstandort mit 60 Acer rubrum und 60 Betula nigra eingerichtet, der typische Störungen durch urbane Landschaftsentwicklung simuliert. Holzhackschnitzelmulch (WC), Kompost (COMP), anorganischer Dünger (FERT), belüfteter Komposttee (ACT), ein kommerzielles biologisches Produkt (CBP) und eine Kontrolle nur mit Wasser (NULL) wurden hinsichtlich ihres Einflusses auf Bodenqualität und Baumwachstum nach fünf Jahren untersucht. Die WC-Behandlung reduzierte signifikant die Körperdichte und die Bodenfeuchte, den organischen Anteil sowie die mikrobielle Atmung. Die COMPBehandlung steigerte die Bodenfeuchte, organische Masse, mikrobielle Atmung, $\mathrm{pH}, \mathrm{N}, \mathrm{P}$ und K. Der Bodengehalt an $\mathrm{P}$ wurde durch die FERT-Behandlung vergrößert. Das Baumwachstum wurde signifikant durch WC, COMP, und FERT-Behandlungen gesteigert. Es wurden keine signifikanten Veränderungen der Bodeneigenschaften und des Baumwachstums bei der Behandlung mit ACT oder CBP im Vergleich zu NULL beobachtet und verglichen mit hintergründigen Bodenebnen oder anderen Behandlungen ( $\mathrm{z}$. B. COMP und WC) liefern ACT und CBP relativ geringe Mengen an Mikroben und Nährstoffen. Diese Forschung liefert einen starken Beweis, dass COMP-Abdeckungen und WC-Mulchen effektiv sind und auch kosteneffiziente Methoden zur Verbesserung der Bodenqualität und Stimulans von Baumwachstum in verdichteten urbanen Landschaftsböden leisten können.

Résumé. La croissance des arbres est grandement affectée par l'enlèvement de la couche de terre arable et la compaction des horizons du sol associés au développement des sites urbains. Une parcelle de recherche a été aménagée comportant 60 Acer rubrum et 60 Betula nigra, reproduisant les perturbations typiques auxquelles est exposé un site urbain. Des paillis de bois raméal fragmenté, du compost, de l'engrais inorganique, du compost de thé, un produit biologique commercial et une irrigation contrôlée ont été mis à l'essai afin d'évaluer leur impact sur la qualité du sol et la croissance des arbres après cinq ans. Le paillis de bois raméal fragmenté a diminué de manière significative la densité volumétrique et a augmenté l'humidité du sol, le taux de matière organique et la respiration microbienne. Pour sa part, le compost a augmenté l'humidité du sol, le pourcentage de matière organique, la respira- tion microbienne, le $\mathrm{pH}$, le taux d'azote, de phosphore et de potassium. Le niveau de phosphore a été amélioré avec l'utilisation de l'engrais inorganique. La croissance des arbres a été améliorée de façon significative avec les traitements de paillage avec bois raméal fragmenté, de compost et d’engrais inorganique. Aucune amélioration significative des propriétés du sol ou de croissance des arbres n'a été observée avec le compost de thé ou le produit biologique commercial par rapport à l'irrigation contrôlée; et par rapport aux parcelles de sols témoins ou aux autres traitements (par exemple, le compost ou le paillis de bois raméal fragmenté) le compost de thé et le produit biologique commercial n'ont fourni que des quantités relativement minimes de microbes et déléments nutritifs. Cette étude démontre que l'utilisation de compost et de paillis de bois raméal fragmenté sont des méthodes efficaces et rentables pour améliorer la qualité des sols et stimuler la croissance des arbres dans les sols compacts rencontrés sur les sites urbains.

Resumen. El crecimiento de los árboles se ve afectado negativamente por la eliminación de la capa superficial y la compactación del subsuelo asociada con el desarrollo de sitios en paisajes urbanos. Se creó una parcela de investigación con 60 Acer rubrum y 60 Betula nigra, imitando la perturbación típica del paisaje urbano. Se evaluaron los tratamientos con mulch de triturado de madera (WC), composta (COMP), fertilizantes inorgánicos (FERT), té de compost aireado (ACT), un producto biológico comercial (CBP) y control con agua (NULL) para conocer sus impactos en la calidad del suelo y crecimiento de los árboles después de cinco años. El tratamiento WC disminuyó significativamente la densidad aparente y aumentó la humedad del suelo, materia orgánica y respiración microbiana. El tratamiento COMP aumentó la humedad del suelo, materia orgánica, respiración microbiana, pH, N, P y K. El P del suelo aumentó con el tratamiento FERT. El crecimiento de los árboles fue significativamente superior con WC, COMP y FERT. No se observaron cambios significativos en las propiedades del suelo o crecimiento de los árboles con ACT o CBP en comparación con NULL; y en comparación con los niveles del suelo u otros tratamientos (por ejemplo, COMP y WC) ACT y CBP aportaron cantidades relativamente mínimas de microorganismos y minerales. Esta investigación muestra fuertes evidencias de que COMP y WC en cobertura y mulches son métodos económicamente eficaces para mejorar la calidad del suelo y estimular el crecimiento de los árboles en suelos compactados en el paisaje urbano. 